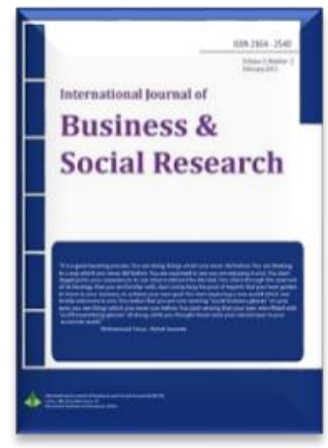

\title{
The Moderating Effect of Knowledge Transfer on Satisfaction-Performance Relationship
}

\author{
Bahtışen Kavak', Ayşegül E. Sertoğlu², Öznur Ö. Tektaș³
}

\begin{abstract}
The purpose of this research is to examine the effect of satisfaction, with its basic antecedents of trust and conflict, on firm performance and to test the moderating effect of dyadic knowledge transfer on the satisfaction and performance relationship. A survey was applied to 193 participants working in medium and small-sized firms, operating in an Organized Industrial Region in AnkaraTurkey. Since measurement items were adapted from different studies, CFA was conducted to test discriminant and convergent validity and the hypothesized paths were tested using LISREL 8.3. The findings reveal that conflict and trust explain $76 \%$ of the satisfaction; and satisfaction itself explains $44 \%$ of the firm performance. As expected, both trust and conflict are proved to be the two indicators of satisfaction. Besides, we found significantly positive effect of satisfaction on firm performance. According to hierarchical moderated regression analysis results, conducted to test moderating effect of knowledge transfer for the whole sample, the interaction of satisfaction and dyadic knowledge transfer imposed negative, insignificant effect on firm performance, hence, hypothesis ( $\left.\mathrm{H}_{4}\right)$ is not supported. Further analysis was conducted by dichotomizing the sample according to knowledge transfer, and research model was tested for each group. The effect of satisfaction on firm performance is found to be significant only when the dyadic knowledge transfer between firms is low, while the effect of is still insignificant when the level of knowledge transfer is high, providing a partial support for $\mathrm{H} 4$.
\end{abstract}

Keywords: Channel member satisfaction, conflict, firm performance, knowledge transfer, trust. Available Online: 06-07-2016.

This is an open access article under Creative Commons Attribution 4.0 License, 2016.

\subsection{INTRODUCTION}

The studies of channel relationships have become an important research area over the past decade. In channel relationships, knowledge sharing, channel member satisfaction and performance have been addressed as crucial channel outcomes and important source of competitive advantage. Of these,

\footnotetext{
${ }^{1}$ Department of Business Administration, Hacettepe University, Ankara, TURKEY. E-mail: bahtisenkavak@gmail.com

2 Corresponding Author. Faculty of Economics and Administrative Science, Department of International Trade, Gazi University, Ankara TURKEY. E-mail: aermec@gazi.edu.tr

3 Faculty of Economics and Administrative Science, Department of Business Administration, Hacettepe University, Ankara TURKEY. E-mail: oznuro@hacettepe.edu.tr
} 
satisfaction is conceptualized as one of the key factors affecting channel relationship (Dwyer, 1980). As the channel members are pleased with the relationships they will probably perform better. Despite its primary role, the effect of satisfaction on performance in distribution channels is a relatively lessstudied issue in channel literature. As channel member satisfaction may help to increase its performance, examining the antecedents of the concept (satisfaction) will become vital. Trust and conflict between channel members have been addressed as two of the most important elements of inter-firm relationships in the literature (e.g. Anderson and Narus, 1990; Dwyer et al., 1987; Geyskens et al., 1998). Trust, by decreasing perceived risk and uncertainty, increases the willingness of channel members to work together, which in turn has a positive impact on firms' satisfaction levels. Contrarily, high levels of conflict negatively affect the firm outcome and cooperation between channel members. Our objective is to understand the most important elements of inter-firm relationships and to test their effects simultaneously in order to provide a more complete insight to distribution channel literature. In today's competitive environment in order to survive; firms need to maintain healthy and long lasting business relationships which depend on basically trust, satisfaction, and less conflict.

Previous studies investigate the direct and indirect relationships among satisfaction, trust and conflict as the antecedents of firm performance (Anderson and Narus, 1990; Skinner et al., 1992; Andaleeb, 1996; Razzaque and Boon, 2003; Duarte and Davies, 2004; Mangin et al., 2008). Yet, we argue that the effects of these three concepts may change depending on some situational factors resulting from the channel relationship. For instance, knowledge sharing has emerged as a strategically significant source of the firm (Lee, 2001) and its role in firm performance and satisfaction is well documented in the literature (i.e. Stank et al., 1996b; Whipple et al., 2002; Kotabe et al., 2003; Kulp et al., 2004; Liu et al., 2009). The essence of these studies is that in general, as the knowledge transfer gets higher, the level of firm satisfaction and performance will be higher. In order to monitor market trends and to survive in the competitive world, firms realized that it is very important to continuously acquire up-to-date market knowledge (Schlegelmilch and Penz, 2002). Market-related information helps firms to be able to respond to customer needs and to create competitive advantage (Dwyer et al., 1987).

Although firms may choose to exchange information with their trading partners in order to improve supply chain performance, they must also balance the risks associated with providing information that can be used against them (Porterfield, 2008). So, knowledge transfer should be considered cautiously and managed carefully in order to lead positive contributions to the partners. However, up to our knowledge, the possible bufferring effect of knowledge transfer on satisfaction and performance relation has not been addressed before. Knowledge transfer between channel members may influence the potential effect of satisfaction on firm performance.

Thus, the aim of this study is to examine the effect of satisfaction with its basic antecedents of trust and conflict, on firm performance, and to test the moderating effect of dyadic knowledge transfer between channel members on satisfaction and performance relationship. More specifically, we argue that buyer firms' satisfaction level will be higher when trust-based and less conflicted relations are developed, and the firms' performance will benefit from this satisfaction level most when a dyadic knowledge transfer is provided.

The paper is structured as follows: First, we provide a review of the literature; next, we propose a research model and present the research hypotheses. After the description of the research methodology, the results are discussed. Finally, limitations and directions for future research are presented.

\subsection{LITERATURE REVIEW}

\subsection{CHANNEL SATISFACTION AND FIRM PERFORMANCE}

Performance is "the degree to which a supplier's relationship with a dealer contributes to fulfillment of the supplier's objective" (Gaski and Nevin, 1985: 131). According to Stern and El-Ansary (1977) high 
performance is important for enlarging the gains of a channel member from the relationship. Channel performance, as an output, can be viewed "as the ultimate objective and the result of channel interaction between two or more firms" (Perry, 2001: 238). In the literature, performance sometimes can be used interchangeably with concepts of "effectiveness" (McMahon and Perritt, 1973), "efficiency" (Rosenbloom, 1973) or "success" (Child, 1974). In all cases, it is seen as the outcome or sum of firm's actions and relations which will help managers to make appropriate decisions in the future (Valos and Vocino, 2006: 18). In the distribution channel literature, performance of a firm is associated with different concepts such as: Dependence (Lewis and Lambert, 1991), commitment (Joshi, 2009; Brown et al., 1995), trust (Anderson and Narus, 1990; Ganesan, 1994; Scheer and Stern, 1992; Vlachos and Bourlakis, 2006; Zaheer et al., 1998), conflict between parties (Perry, 2001; Zaheer et al., 1998; Lusch, 1976), power (Brown et al., 1995), knowledge-technology transfer (Dhanaraj et al., 2004; Kotabe et al., 2003; Porterfield, 2008) and satisfaction (Robicheaux and El-Ansary, 1975-6).

Among others, satisfaction in a distribution channel is one of the mostly studied antecedents of firm performance. It is defined as a positive, affective state resulting from the appraisal of all aspects of a firm's working relationship with another firm (Frazier et al., 1989; Gaski and Nevin, 1985; Liu et al., 2009). Satisfaction in a distribution channel is an important characteristic of inter-firm relationship quality and continuity (Ping, 2003), or in general, of a well-functioning marketing channel relationships (Dwyer, 1980; Robicheaux and El-Ansary, 1975-6). According to Geyskens et al. (1999), satisfaction involves both economic (i.e. sales volume, margins) and non-economic (i.e. affective and psychosocial) aspects of the relationship (Geyskens et al. 1999; Geyskens and Steenkamp, 2000). Another view (Payan and McFarland, 2005) accepts satisfaction as the overall satisfaction and/or happiness in the relationship between firms. In this study we considered overall satisfaction about the all aspects of the relationship.

Scholars (e.g. Robicheaux and El-Ansary, 1975-6; Lewis and Lambert, 1991; Lai, 2007) state that channel member satisfaction improve firm performance by providing a number of advantages for channel members such as; encouraging participation in collective activities (Razzaque and Boon, 2003; Schul et al., 1985); leading to higher morale, greater cooperation, reducing terminations of relationships and lower likelihood of seeking protective legislation (Hunt and Nevin, 1974). It also helps in developing integrated logistics management and just-in time inventory systems (Brown et al., 1991), and provide long-run channel viability (Dwyer, 1980). According to Gaski (1984), as the attitude will lead to change in behavior, the channel's performance also varies with satisfaction. As satisfaction represents the positive affective response on the relationships between channel members and other channel partners (Frazier et al., 1989), members may perform beter when they are content with the channel relationships (Lai, 2007). Therefore, it is hypothesized:

H1: The buyer firm's satisfaction level has a direct and positive effect on firm performance.

\subsection{THE EFFECTS OF TRUST AND CONFLICT}

In today's competitive markets, to develop joint marketing programs (Johanson and Mattson, 1985) and to increase their performance (Vlachos and Bourlakis, 2006); channel members are increasingly looking for having fewer but stronger relationships with their partners (Geyskens et al., 1998). Need for strong relationships has lead researchers to study trust in distribution channels and consider it as one of the main construct of channel relationships (Anderson and Weitz, 1989; Morgan and Hunt, 1994; Razzaque and Boon, 2003). Trust is conceptualized as "the willingness of a party to rely on the behaviors of others, especially when these behaviors have outcome implications for the party bestowing trust" (Razzaque and Boon, 2003, p.26). Trust, by reducing the uncertainty about the outcomes in the relationship, make one part feel confident and contended about the relationship (Razzaque and Boon, 2003), also fosters cooperation (Morgan and Hunt, 1994), and increase commitment (Morgan and Hunt, 1994; Andaleeb, 1996; Razzaque and Boon, 2003). Thus, trust is necessary before inter-firm joint activities to take place (Duarte and Davies, 2004; Morgan and Hunt, 1994). 
Previous studies (e.g. Dwyer et al., 1987; Anderson and Narus, 1990; Geyskens et al., 1998; Duarte and Davies, 2004) empirically support the positive relationship between trust and satisfaction. When a channel member trusts his partner, he will feel secure due to an implicit belief that the partner has sincere intentions (Geyskens and Steenkamp, 1995) and will act to promote positive outcomes or avoid negative outcomes for the partner (Geyskens et al., 1998) which leads to higher satisfaction with the channel relationship (Andaleeb, 1996). Anderson and Narus, (1990) studied a model in a distributor and manufacturer working partnerships by considering both manufacturer and distributor perspectives and found a positive relationship between trust and satisfaction for manufacturers. Geyskens et al., (1998) tested the mediating role of trust between environmental uncertainty, communication, and satisfaction and also found that trust contributes to firm satisfaction. Razzaque and Boon, (2003) used an experimental design to test the effect of trust on satisfaction for managers and executives with corporate buying and selling and revealed that higher levels of trust leads to higher levels of satisfaction. According to Duarte and Davies, (2004), satisfaction with the relationship appeared to emerge from an evaluation after a significant time period and they interpreted this as satisfaction being a consequence of trust. Based on previously mentioned studies, the second hypothesis of the study is:

H2: The buyer firm's trust for the supplier has a direct and positive effect on satisfaction.

Conflict exists in a channel when "a member perceives the behavior of the other to be impeding the attainment of its goals or the effective performance of its instrumental behavior patterns" (Etgar, 1979: 61) and is conceptualized as an antecedent of satisfaction of a distribution channel member (Anderson and Narus, 1990; Mangin et al., 2008). In distribution channels conflict can be either functional or dysfunctional (Hunt, 1995). In a number of studies (Goldman, 1966; Etgar, 1979; Rosenberg and Stern, 1970) conflict is defined as being dysfunctional that is a behavior designed to destroy, injure, frustrate or control another member in an interdependent relationship (Mack and Synder, 1957). Other studies (Rosenbloom, 1973; Hunt, 1995), on the other hand, claim that conflict is a functional concept where some level of conflict results in long term benefits to channel members. Consistent with the previous research in distribution channel literature (Rosenberg and Stern, 1971; Wilkinson, 1981; Dwyer, 1980; Anderson and Narus, 1990; Mangin et al., 2008), in this study conflict is conceptualized as a dysfunctional concept. Disagreements between parts may block achievement of the firm's goals, and thereby cause feelings of unpleasantness about the partnership (Anderson and Narus, 1990) and this may destroy the satisfaction level of the buyer firms which in turn affect the performance level.

Conflict and satisfaction relation, that higher conflict between buyer and supplier firms leads lower buyer firm satisfaction, is studied for different industries and countries in distribution channel literature. Anderson and Narus, (1990) studied a model in a distributor and manufacturer working partnerships and posited a negative causal link between conflict and satisfaction, and supported this assertion from the manufacturers' perspective. Skinner et al., (1992) studied the farm and power equipment dealers in the USA and revealed a negative relationship between conflict and satisfaction. Similarly, Duarte and Davies, (2004) analyzed the effect of conflict on satisfaction and found a direct, negative effect. Mangin et al., (2008) analyzed relationships between manufacturers and Canadian dealerships selling American cars by examining, in particular, the level of satisfaction of the latter with the manufacturers; and found a negative effect of conflict on satisfaction. Based on the previous empirical findings we hypothesized that:

H3: The buyer-supplier conflict level has a direct and negative effect on buyer firm satisfaction.

\subsection{THE MODERATING EFFECT OF KNOWLEDGE TRANSFER}

In this study, a direct effects model among the main three antecedents of firm performance was proposed. In addition, it can be argued that buyer-supplier relationships that have high knowledge transfer are better able to exploit their performance by utilizing trust and decreasing conflict. Interorganizational knowledge transfer refers to a process of conveying knowledge between members of 
an exchange relationship (Bresman et al., 1999; Griffith et al., 2001), through which one exchange member is affected by the experience of another (Inkpen and Tsang, 2005). The knowledge transfer in a channel relationship can be both bidirectional (Bresman et al., 1999) and unilateral (Liu et al., 2009) such as the transfer of market knowledge from a distributor to a manufacturer or vice versa. In this study we considered knowledge transfer from supplier to buyer and from buyer to supplier in order to analyze the effects of the transfer more comprehensively. Following this argument, adding the moderating effect of knowledge transfer to the research model may contribute to the model's exploratory value. Thus, three interactions have been added in this study's research model.

Variables which affect performance and satisfaction individually may become potential moderators of the relationship between these two concepts (Schwab and Cummings, 1970). Knowledge transfer has been shown to be related to both performance (e.g. Glazer, 1991; Stank et al., 1996a; Kotabe et al., 2003; Porterfield, 2008; Lakshman and Parente, 2008) and satisfaction (e.g. Stank et al., 1996b; Whipple et al., 2002, Lakshman and Parente, 2008; Liu et al., 2009; Rodrí guez et al., 2006) Information sharing between trading partners can improve performance (Bruns and McFarlan, 1987).

Therefore, since knowledge transfer has been shown to be related to satisfaction (Whipple et al., 2002; Rodri'guez et al., 2006), it seems appropriate to expect knowledge transfer to moderate the relationship between satisfaction and performance (Pettit et al., 1997). Thus, going a step further in order to provide more in depth insight, the current study asserts that knowledge transfer possibly exerts an effect on the satisfaction and performance relationship.

H4: Knowledge transfer between the seller and the buyer moderates the relationship between buyer satisfaction and buyer performance.

\subsection{DATA AND METHODOLOGY}

\subsection{THE RESEARCH MODEL AND HYPOTHESES}

The research model of the study (Figure 1) proposed that trust and conflict between buyer and seller firms have a direct impact on buyer firm satisfaction $\left(\mathrm{H}_{2}\right.$ and $\left.\mathrm{H}_{3}\right)$ which in turn positively affect the firm performance $(\mathrm{H} 1)$. Besides these direct effects, model also proposes moderating effect of knowledge transfer on satisfaction and performance relationship $\left(\mathrm{H}_{4}\right)$.

Figure 1: Research model

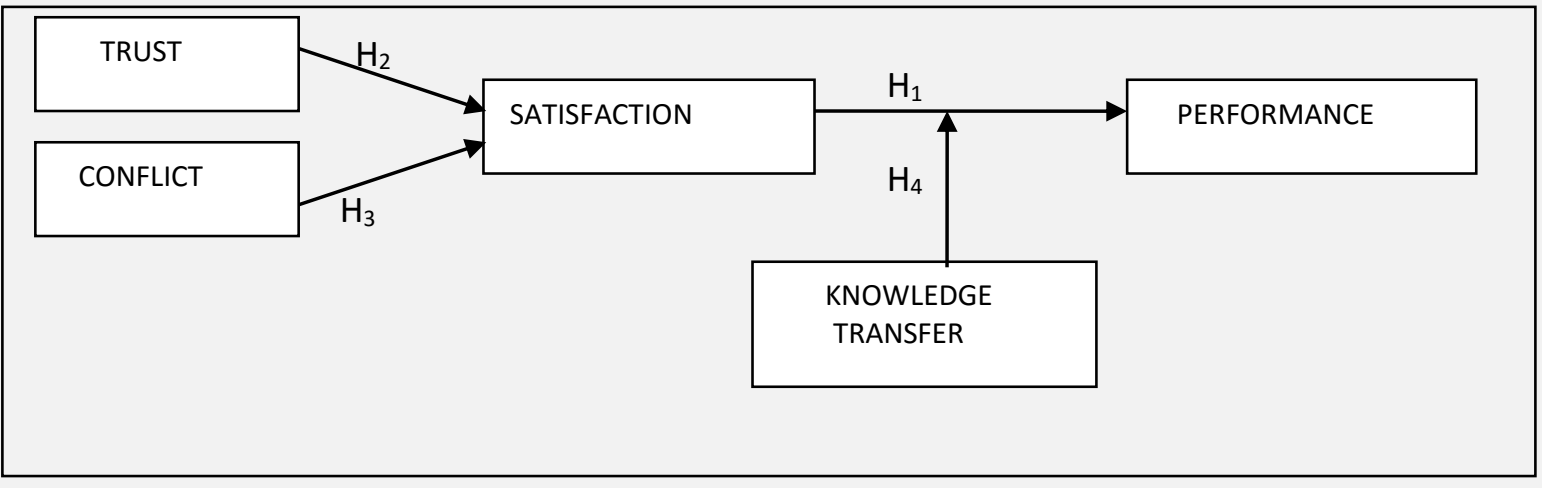

\subsection{MEASURES}

All of the measurement items of research model variables were adopted from relevant literature and five-point Likert-type scale was used (1=strongly disagree and 5=strongly agree). Since the questionnaire was administered in Turkish, it was developed originally in English and backward-forward 
translated. A pilot study was conducted by 30 firms and it is assessed that the questions were clear enough.

Most of performance measurements are quantitative such as costs, sales, profitability etc. According to Perry, (2001) performance can be viewed as a behavioral construct and, because "these measures overlook behavioral relationships or interactions" (Perry, 2001: 238), it should be measured perceptually. Hence, performance of the firms was measured based on perceptions, by five items relying on measures used by Kotabe et al., 2003 and Hernandez-Espallardo and Arcas-Lario (2008). According to Kotabe et al., (2003), the measure of performance captures the performance improvement relative to $2-3$ years earlier. The measure includes dimensions of operational performance. The next two items were chosen from the study of Hernandez-Espallardo and Arcas-Lario (2008) and these were asked to measure the economic performance. The reliability of the scale was calculated using Cronbach's Alpha which was 90\%. In order to measure satisfaction, we browed and modified two items from Payan and McFarland, (2005) and one each from Kumar et al. (1992) and Razzaque and Boon, (2003). The items were chosen to express overall satisfaction. Cronbach's Alfa was 91\% for satisfaction. Relying on the scale used by Kumar et al. (1992), we took and modified three items to measure perceived conflict level for the buyer (manufacturer). In this study conflict is accepted as dysfunctional. Trust was measured by seven items four of them were adopted from isşçimen (2007), and three items adopted from Razzaque and Boon, (2003). Cronbach's Alfas were $86 \%$ for conflict and 90\% for trust scale. Finally, Knowledge Transfer measured with seven items, "pertaining to knowledge exchange focused on operational issues where operational was defined as -decisions and actions that affect both partners' short-term planning and day-to-day performance", derived from Whipple et al., (2002). Cronbach's Alfa was \%84 for knowledge transfer items. All of the measurement items are presented in Appendix A.

\subsection{SAMPLING AND DATA COLLECTION}

The data was collected from medium and small-sized firms operating in Middle East Industry and Trade Center (OSTIM) which is an Organized Industrial Region in the capital city of Turkey-Ankara. Selfadministered, structured questionnaire was used as data collection method. Convenience sampling technique was used since the full list of the firms was not available. The total sample size, after eliminating questionnaires with high levels of missing data and outliers, was 193 with a response rate of 40\%. The sample included $91 \%$ small-sized firms which had less than 50 employees. Total of 121 firms (64\%) work with the same supplier less than five years. At average $35 \%$ of the participants have college degree and $37 \%$ have high school education. The industries covered were textile, food, manufacture, service, construction and retail. Table 1 lists means, standard deviations of the constructs, and correlation coefficients among them.

\begin{tabular}{lrrrrrrr}
\hline & Table 1: Means, Standard Deviations and Correlation Matrices & & \\
& $\mathbf{1}$ & $\mathbf{2}$ & $\mathbf{3}$ & $\mathbf{4}$ & $\mathbf{5}$ & Mean & SD \\
\hline 1. Conflict & 1.00 & & & & & 2.18 & 0.85 \\
2. Trust & -0.59 & 1.00 & & & & 3.56 & 0.87 \\
3. Satisfaction & -0.69 & 0.75 & 1.00 & & & 3.75 & 0.85 \\
4.Knowledge Transfer & -0.47 & 0.80 & 0.63 & 1.00 & & 3.85 & 0.68 \\
5. Performance & -0.42 & 0.70 & 0.60 & 0.71 & 1.00 & 3.72 & 0.82 \\
\hline
\end{tabular}

Note: Correlation is significant at the 0.01 level (2-tailed).

\subsection{EMPIRICAL FINDINGS}

\subsection{DATA SCREENING}

In order to detect convergent and discriminant validity we used correlation coefficients between items of both independent and dependent variables. Results showed that there are high correlations between inter-variable items which provide support for convergent validity (Correlation coefficients are 
between 0.46 and 0.85 ). For discriminant validity, correlation coefficients between items of different variables were lower (between 0.20 and 0.53 ) indicating that independent variables are not related. For the multicollinearity, results of correlations between independent variables (smaller than $80 \%$ ), Tolerance rates (greater than .40) and Variance Inflation Factors (smaller than 2.5) indicated that there were not multicollinearity between IVs. Since convenience sampling technique was used, the data was also tested for randomness by Runs test. Results showed that the measurement items were randomly distributed.

Since measurement items were adapted from different studies, CFA was conducted to test convergent validity. All standardized residuals were smaller than one and measurement factor loadings ( $t$-values) were greater than recommended 0.4 cutoff and were statistically significant at level of .05 (Nunnally and Bernstein, 1994). The estimates generated by LISREL 8.3 provided evidence of a satisfactory model fit $\left(\chi^{2}=708.84 ; \mathrm{GFI}=0.78, \mathrm{CFI}=0.89 ; \mathrm{RMSEA}=0.088\right.$ ) (Hair et al., 1998). Table 2 presents the CFA results.

\begin{tabular}{|c|c|c|c|}
\hline \multicolumn{4}{|c|}{ Table 2: CFA results of measures } \\
\hline Constructs* & Loadings & t-value** & AVE \\
\hline \multicolumn{4}{|l|}{ Performance } \\
\hline $\mathrm{P}_{1}$ & 0.83 & 13.78 & 0.69 \\
\hline $\mathrm{P} 2$ & 0.85 & 13.61 & 0.68 \\
\hline P3 & 0.75 & 13.13 & 0.65 \\
\hline $\mathrm{P}_{4}$ & 0.77 & 12.41 & 0.60 \\
\hline $\mathrm{P}_{5}$ & 0.72 & 12.56 & 0.61 \\
\hline \multicolumn{4}{|l|}{ Satisfaction } \\
\hline S1 & 0.82 & 15.33 & 0.78 \\
\hline S2 & 0.86 & 16.39 & 0.84 \\
\hline S3 & 0.80 & 15.72 & 0.80 \\
\hline S4 & 0.78 & 12.61 & 0.60 \\
\hline \multicolumn{4}{|l|}{ Conflict } \\
\hline $\mathrm{C} 1$ & 0.80 & 13.97 & 0.71 \\
\hline $\mathrm{C}_{2}$ & 0.84 & 16.20 & 0.86 \\
\hline$C_{3}$ & 0.73 & 11.15 & 0.52 \\
\hline \multicolumn{4}{|l|}{ Trust } \\
\hline T1 & 0.93 & $13 \cdot 36$ & 0.65 \\
\hline $\mathrm{T} 2$ & 0.94 & 12.88 & 0.62 \\
\hline T3 & 0.79 & 12.72 & 0.61 \\
\hline T4 & 0.78 & 10.34 & 0.45 \\
\hline T5 & 0.87 & 14.49 & 0.72 \\
\hline T6 & 0.76 & 10.98 & 0.50 \\
\hline T7 & 0.75 & 11.90 & 0.56 \\
\hline \multicolumn{4}{|c|}{ Knowledge Transfer } \\
\hline $\mathrm{KT} 1$ & 0.78 & 13.02 & 0.64 \\
\hline $\mathrm{KT} 2$ & 0.69 & 11.86 & 0.57 \\
\hline KT3 & 0.48 & 9.48 & 0.40 \\
\hline KT4 & 0.53 & 9.68 & 0.42 \\
\hline KT5 & 0.66 & 9.00 & 0.37 \\
\hline KT6 & 0.56 & 8.42 & 0.33 \\
\hline KT7 & 0.53 & 8.12 & 0.31 \\
\hline
\end{tabular}

\subsection{HYPOTHESIS TESTING}

The hypotheses of the study were tested in LISREL 8.3 (Jöreskog and Sörbom, 1999) using MaximumLikelihood estimation procedure and covariance matrix since the data was continuous (Hair et al., 1998, 
p.605). Goodness of fit statistics indicate a good fit of the data. The ratio of $\chi_{2} / d f$ is 1.98 , less than the cut-off point of 2. Other fit indices including RMSEA (0.095), GFI (0.81) and CFI (0.91) indicate that proposed model of the study has a satisfactory fit. In addition, explained variances indicate high predictive power of dependent variables. Conflict and trust explain $76 \%$ of the satisfaction; and satisfaction itself explains $44 \%$ of the firm performance.

Standardized path estimates, t-values and variance explained ( $\left.R_{2}\right)$ in dependent variables provided support for the first three hypotheses (see Figure 2). As expected, both conflict and trust are two indicators of satisfaction. That is, conflict has a significant and negative effect on satisfaction (-0.36, tvalue $=-4.95, p<.01)$, while trust has a positive and significant effect on satisfaction $(6.75, t$-value $=6.75$, $\mathrm{p}<.01$ ). Thus, both $\mathrm{H}_{2}$ and $\mathrm{H}_{3}$ are supported. Moreover, satisfaction has a positive, significant effect on firm performance $(.66, \mathrm{t}$-value $=7.29, \mathrm{p}<.01)$ which provides support for $\mathrm{H} 1$.

Figure 2: Overall Model Test, SEM Results of $\mathrm{t}$-values and Standardized Estimates

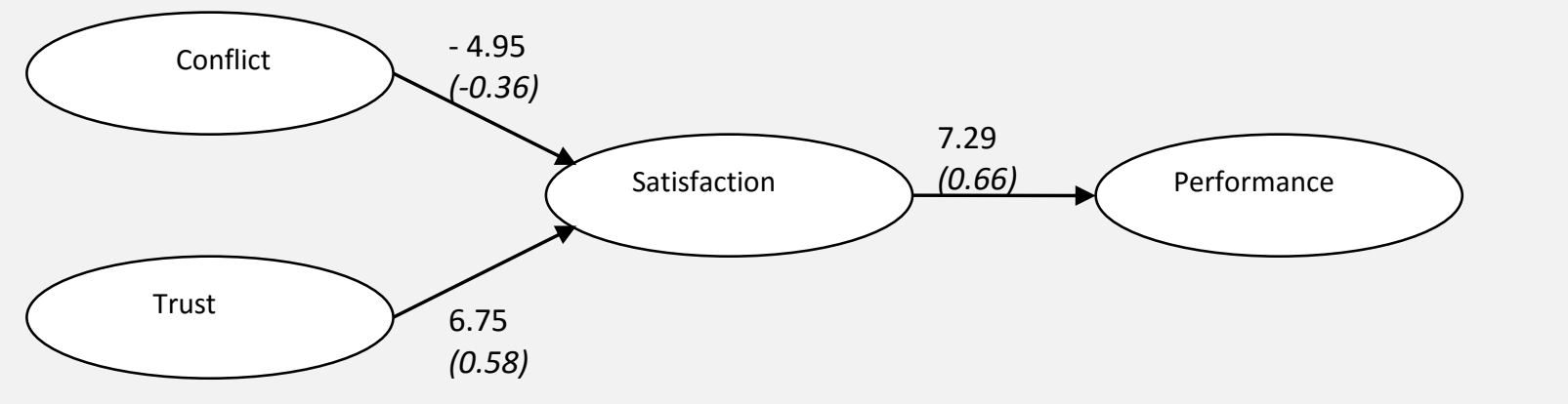

For testing the moderator effect of knowledge transfer, hierarchical moderated regression analysis was conducted proposed by Baron and Kenny (1986). Initially, a regression of firm performance with both satisfaction and knowledge transfer was conducted. The results approved that satisfaction has a significant effect $(\beta=0.24 ; p<.01)$ which provide additional support for $\mathrm{H} 1$. Further, it was revealed that knowledge transfer has a positive, significant effect on firm performance $(\beta=0.55 ; p<.01)$. In the second step of the hierarchical regression analysis, the interaction of satisfaction and knowledge transfer imposed negative, insignificant effect on firm performance $(\beta=-.06 ; p=.214 ; \Delta R 2=0.04)$. Hence, the $\mathrm{H} 4$ is not supported.

Given the insignificant moderating effect of knowledge transfer for the whole sample, further analysis was conducted by dichotomizing the sample according to knowledge transfer. Two sub-groups were formed for above and below the mean of knowledge transfer, and research model was tested for each group by using LISREL 8.3. The difference between two models was tested by Chi-square difference test. Goodness of fit statistics, $t$-values, standardized estimates and explained variance rates for each group was presented at Table 3 .

Table 3: Research model test for low and high levels of knowledge transfer

\begin{tabular}{lcrrr} 
& \multicolumn{2}{c}{$\begin{array}{c}\text { Low Knowledge } \\
\text { t-value }\end{array}$} & SPE & \multicolumn{2}{c}{ High Knowledge Transfer } \\
Hypothesized Path & $-3.46^{*}$ & -0.45 & $-3.93^{*}$ & SPE \\
\hline Conflict $\rightarrow$ Satisfaction & $3.58^{*}$ & 0.50 & $4.15^{*}$ & -0.40 \\
Trust $\rightarrow$ Satisfaction & $4.10^{*}$ & 0.58 & $1.94(\mathrm{~ns})$ & 0.43 \\
Satisfaction $\rightarrow$ Performance & & & & 0.21 \\
Goodness of Fit Statistics & & 0.097 & \\
RMSEA & & 265.41 & 0.113 \\
Chi-Square & 146 & & 457.52 \\
Df & & 0.76 & 148 \\
GFI & 0.85 & & 0.72 \\
NNFI & & 0.87 & 0.79 \\
CFI & & & 0.82
\end{tabular}




\section{Explained Variances}

Satisfaction

* $\mathrm{p}<0.05$, ** $d f=2, \Delta \chi^{2}=192.16, p<0.001, n s=$ not significant, SPE $=$ Standardized Path Estimates

According to results, first of all, the difference between high and low knowledge transfer models is significant according to Chi-square difference test $\left(\mathrm{df}=2, \Delta \chi_{2}=192.16, \mathrm{p}<0.001\right)$. Comparing the outputs of two models, we can say that knowledge transfer makes a difference on the effect of satisfaction on performance which provides partial support for the fourth hypothesis of the study. More specifically, the effect of satisfaction on firm performance is significant (0.58; t-value $=-3.46 ; p<.01)$ only when the knowledge transfer between firms is low. Yet, when the level of knowledge transfer is high, the effect of satisfaction on performance is insignificant.

\subsection{RESULTS AND DISCUSSION}

This paper has attempted to examine first the effects of trust and conflict between channel members as the antecedents of firm satisfaction which in turn has impact on firm performance and second, to test the moderating effect of dyadic knowledge transfer between channel members. As expected, both conflict and trust are two indicators of satisfaction. That is, conflict has a significant and negative effect on satisfaction, while trust has a positive and significant effect on satisfaction. Also, the results show that satisfaction has a positive, significant effect on firm performance. Partial support was provided for the moderating effect of knowledge transfer on firm performance through satisfaction. Accordingly, knowledge transfer makes a difference on the effect of satisfaction on performance. More specifically, the effect of satisfaction on firm performance is significant only when the knowledge transfer between firms is low. Yet, when the level of knowledge transfer is high, the effect of satisfaction on performance is insignificant. Additionally, the effect of conflict and trust on satisfaction remains almost the same for low and high levels of knowledge transfer.

Supporting the related literature this study revealed that a buyer will be more satisfied when he trusted the supplier and the level of conflict between parts is low. Herein, conflict resolution comes up as an important issue in channel relationships. Also, suppliers should give importance to keep promises in order to create a trustful relationship.

Knowledge transfer between supplier and a buyer has a positive effect on the satisfaction level of the buyer and also the buyer's performance. The transfer of accurate, detailed and timely information between parts, makes the buyer feel more comfortable and satisfied, and also increases the performance level of the buyer. The positive effect of satisfaction on performance is valid when the knowledge transfer level is low between the supplier and the buyer, while this relationship is insignificant when the knowledge transfer level is high. A possible explanation for this finding should be the disconfirmation of expectations theory. It suggests satisfaction is a function of performance perceptions and positive disconfirmation of prior expectations (Wang and Olsen, 2002). According to the theory, satisfaction is an outcome of a process whereby prior expectations or standards are compared with actual performance perceptions. As the knowledge transfer between parts increases, the buyer's expectations may also increase which in turn may lead to negative disconfirmation that occurs when actual performance is perceived as falling short of expectations. The level of satisfaction under low and high knowledge transfer should be a supporting evidence. The satisfaction level of the buyer is lower in the case of high knowledge transfer than in the case of low knowledge transfer (mean=3.29 in the case of high knowledge transfer, mean=4.13 in the case of high knowledge transfer). Also the reason of insignificant relationship between satisfaction and performance in the case of high knowledge transfer should be this decrease in satisfaction level.

An other possible explanation for this sould be provided. Knowledge transfer should be perceived negatively by the parts. The fear of individualization and violation of right of privacy as the knowledge 
transfer increases may also distort the satisfaction-performance relationship. Further research should help to shed light on this issue.

\subsection{CONCLUSION AND POLICY IMPLICATIONS}

This study aimed at investigating channel member's satisfaction and performance relationship. The direct effects of trust and conflict on satisfaction, and the moderating effect of knowledge transfer on satisfaction-performance relationship was investigated.

In line with the expectations, conflict had a significant and negative effect on satisfaction, while the impact of trust was significantly positive. Trust reduces perceived uncertainty about the outputs to be obtained from the relationship (Razzaque and Boon, 2003) and parties believe in that the partner has sincere intentions (Geyskens and Steenkamp, 1995) and will act to promote positive outcomes for them (Geyskens et al., 1998). These beliefs, in turn, lead to higher satisfaction with the channel relationship (Andaleeb, 1996). For these reasons, if managers can take steps, such as keeping promises, complying with the timing and taking into account the interests of the other party, to ensure that the other party to rely on themselves, a satisfactory relationship for both parties can be established in the long run.

Managing a dysfunctional conflict (Dwyer, 1980; Anderson and Narus, 1990; Mangin et al., 2008) can also be stated as an important task for managers. As disagreements between partners may block achievement of the firm's goals, conflict may destroy the satisfaction level of the firms. As managers understand the other party's objectives and help them to facilitate the achievement of their goals (Sashi, 2009), conflict will decrease and satisfaction level, in turn, will increase.

Findings of this study confirmed that satisfaction has a significantly positive effect on firm performance. This result is compatible with the expectations and revealed that prerequisite to being successful is a satisfactory relationship between channel members. As stated above, by managing conflict and creating a mutual trust environment, firms can improve the satisfaction level of their partners and also their performances. With increases in firm performance levels, both parts will endeavor for the continuity of the relationship voluntarily.

Partial support provided for the moderating effect of knowledge transfer on satisfaction and performance relationship is another important contribution of this study and should be overemphasized. Accordingly, the transfer of accurate, detailed and timely information between parts, makes the buyer feel more comfortable and satisfied, and also increases the performance level of the buyer. The positive effect of satisfaction on performance is valid when the knowledge transfer level is low between the supplier and the buyer, while this relationship is insignificant when the knowledge transfer level is high. As the knowledge transfer between parts increases, the buyer's expectations from the partner and the relationship may also increase. In that case, parties' evaluation of their performance may be less than expected. Therefore, content and amount of the transferred knowledge should be determined carefully, in order not to excite the anticipations of the partner.

Overall, our study underlines the importance of relationship management in a marketing channel. Preventing dysfunctional conflicts and creating a mutual trust environment are two of the most important tasks of the managers. For the success of the channel relationship the dyadic knowledge transfer process, also, should be handled carefully by both parties.

Although this study provides new insights, there are some limitations which should be addressed in future research. First, all the hypotheses were tested for small and medium sized firms and the possible differences between industries were ignored. Further research should be extended to include medium and large scaled firms and sectoral differences should be considered. Buyer side should be considered as manufacturers or distributors separately. The sample size should also be increased. 
In addition to the previous implications, we can introduce some issues for future research. As it is addressed in some researches (eg. Geyskens and Steenkamp, 2000; Liu et al., 2009) satisfaction can be considered by classifying it as economic and non-economic satisfaction and the effects of them on performance should be analyzed separately. The moderating effect of knowledge transfer should be different for different satisfaction types. The effect of non-economic satisfaction on performance should be higher as knowledge transfer increases non-economic satisfaction includes the member's positive affective response to the affective and psychosocial aspects of the relationship (Geyskens et al. 1999; Geyskens and Steenkamp, 2000).

In this study, the moderating effect of dyadic knowledge transfer has been investigated. Herein, both the knowledge transfers from the supplier to buyer, and from buyer to supplier has been considered. On the other hand, the effect of unilateral knowledge transfer may reveal different results. Therefore, moderating effect of this unilateral transfer should be studied.

Other possible moderators should be included in the model. For example, factors such as duration of the relationship (Kotabe et al., 2003) that may possibly effect the buyer and seller relation should be considered.

\section{REFERENCES}

Andaleeb, S. S., (1996). An experimental investigation of satisfaction and commitment in marketing channels: the role of trust and dependence. Journal of Retailing, 72 (1): 77-93.

Anderson, J.C. and Narus, J.A., (1990). A model of distributor firm and manufacturer firm working partnerships. Journal of Marketing (January): 42-58.

Anderson, E. and Weitz, B., (1989). Determinants of continuity in conventional industrial channel dyads. Marketing Science, 8(4):310-323.

Baron, R. M. and Kenny, D. A., (1986). The moderator-mediator variable distinction in social psychological research: conceptual, strategic, and statistical considerations. Journal of Personality and Social Psychology, 51: 1173-1182.

Bresman, H., Birkinshaw, J. and Nobel, R., (1999). Knowledge transfer in international acquisitions. Journal of International Business Studies, 30(3): 439-462.

Brown, J.R, Lusch, R.F. and Nicholson, C.Y., (1995). Power and relationship commitment: their impact on marketing channel member performance. Journal of Retailing, 71 (4): 363-392.

Brown, J.R., Lusch, R.F. and Smith, L.P., (1991). Conflict and satisfaction in an industrial channel of distribution. International Journal of Physical Distribution and Materials Management, 21 (6): 15-26.

Bruns, W.J.- Jr and McFarlan, F.W., (1987). Information technology puts power in control systems. Harvard Business Review, 65 (September/October): 89-94.

Child, J., (1974). What determines organizational performance? The universals vs. it-alldepends. Organization Dynamics, 3, Summer: 2-18.

Dhanaraj, C., Lyles, M. A., Steensma, H.K. and Tihanyi, L., (2004). Managing tacit and explicit knowledge transfer in IJVs: the role of relational embeddedness and the impact on performance. Journal of International Business Studies, 35: 428-442.

Duarte, M. and Davies, G., (2004). Trust as a mediator of channel power. Journal of Marketing Channels, 11(2/3): 77-102.

Dwyer, F.R., (1980). Channel-member satisfaction: laboratory insights. Journal of Retailing, 56(2): 45-65.

Dwyer, F. R., Schurr, P.H. and Oh, S., (1987). Developing buyer-seller relationships. Journal of Marketing, 51 (April): 11-27.

Etgar, M., (1979). Sources and types of intrachannel conflict. Journal of Retailing, 55(1): 382-390.

Frazier, G. L., Gill, J. D. and Kale, S.H., (1989). Dealer dependence levels and reciprocal actions in a channel of distribution in a developing country. Journal of Marketing, 53 (January): 50-69.

Ganesan, S., (1994). Determinants of long-term orientation in buyer-seller relationships. Journal of Marketing, 58(April): 1-19. 
Gaski, J.F. and Nevin, J.R., (1985). The differential effects of exercised and unexercised power sources in a marketing channel. Journal of Marketing Research, 22 (May): 130-142.

Gaski, J.F., (1984). The theory of power and conflict in channels of distribution. Journal of Marketing, 48 (Summer): 9-29.

Geyskens, I. and Steenkamp, J.-B.E.M., (1995). An investigation into the joint effects of trust and interdependence on relationship commitment. In: Proceedings of the 24th Annual Conference of the European Marketing Academy: 351-371.

Geyskens, I. and Steenkamp, J.-B.E.M., (2000). Economic and social satisfaction: measurement and relevance to marketing channel relationships. Journal of Retailing, 76(1): 11-32.

Geyskens, I., Steenkamp, J.-B.E.M. and Kumar, N., (1998). Generalizations about trust in marketing channel relationships using meta-analysis. International Journal of Research in Marketing, 15: 223248.

Geykens, I., Steenkamp, J.-B.E.M. and Kumar, N., (1999). A meta-analysis of satisfaction in marketing channel relationships. Journal of Marketing Research, 36: 223-238.

Glazer, K., (1991). Marketing in an information-intensive environment: strategic implications of knowledge as an asset. Journal of Marketing, 55(4): 1-19.

Goldman, R.M., (1966). A theory of conflict processes and organizational offices. Journal of Conflict Resolution: 328-343.

Griffith, D. A., Zeybek, A. Y. and O'Brien, M., (2001). Knowledge transfer as a means for relationship development: a Kazakhstan-foreign international joint venture illustration. Journal of International Marketing, 9(2): 1-18.

Hair, J. F., Anderson, R.E., Tahtam, R.L. and Black, W.C., (1998). Multivariate Data Analysis. Prentice Hall, 5th Edition.

Hernandez-Espallardo, M. and Arcas-Lario, N., (2008). Outcome- and behaviour-control in distribution partnerships: the role of trust and dependence and their effects on performance. The International Review of Retail, Distribution and Consumer Research, 18(1) (February): 63-86.

Hunt, K. A., (1995). The relationship between channel conflict and information processing. Journal of Retailing, 71(4): 417-436.

Hunt, S.D. and Nevin, J.R., (1974). Power in a channel of distribution: sources and consequences. Journal of Marketing Research, 2 (May): 186-193.

Inkpen, A. C. and Tsang, E.W.K., (2005). Social capital, networks and knowledge transfer. Academy of Management Review, 30(1): 146-165.

isş̧imen, E., (2007). Antecedents of buyer's trust in marketing channels and an implementation in Turkish valve market. Unpublished master's thesis Marmara University, Institute of Social Sciences, İstanbul.

Johanson, J. and Mattsson. L.-G., (1985). Marketing investments and market investments in industrial Networks. International Journal of Research in Marketing, 2 (3): 185-195.

Joshi, A. W., (2009). Continuous supplier performance improvement: effects of collaborative communication and control. Journal of Marketing, 73(January): 133-150.

Jöreskog, K. G. and Sörbom, D., (1993). LISREL8: Structural equation modelling with the SIMPLIS command language. Hillsdale, NJ: Erlbaum.

Kotabe, M., Martin, X. and Domoto, H., (2003). Gaining from vertical partnerships: knowledge transfer, relationship duration, and supplier performance development in the U.S and Japanese automotive industries. Strategic Management Journal, 24(4): 293-316.

Kulp, S. C., Lee, H. L. and Ofek, E., (2004). Manufacturer benefits from information integration with retail customers. Management Science, 50 (4) (April): 431-444.

Kumar, N., Stern, L.W. and Achrol, R. S., (1992). Assessing reseller performance from the perspective of the supplier. Journal of Marketing Research, 29 (May): 238-253.

Lai,C.-S., (2007). The effects of influence strategies on dealer satisfaction and performance in Taiwan's motor industry. Industrial Marketing Management, 36: 518-527.

Lakshman, C. and Parente, R.C., (2008). Supplier-focused knowledge management in the automobile industry and its implications for product performance. Journal of Management Studies, 45(2) (March): 317-342. 
Lewis, M. C. and Lambert, D. M., (1991). A model of channel member performance, dependence, and satisfaction. Journal of Retailing, 67 (2): 205 - 225.

Liu, Y., Li, Y. and Xue, J., (2009). Transfer of market knowledge in a channel relationship: impacts of attitudinal commitment and satisfaction. Industrial Marketing Management, 39 (2) (February): 229239.

Lusch, R. F., (1976). Channel conflict: its impact on retailer operating performance. Journal of Retailing, 52: 89-90.

Mack, R. W. and Snyder, R.C., (1957). The analysis of social conflict--toward an overview and synthesis. Conflict Resolution: 212-248.

Mangin, J-P.L., Koplyay, T. and Calmès, C., (2008). The moderator effect of communication in marketing channels of distribution; the case of car's industry in Canada. International Advances in Economic Research, 14: 48-64.

McMahon, J.T. and Perritt, G.W., (1973). Toward a contingency theory of organizational control. Academy of Management Journal, 16 (4): 624-635.

Morgan, R. M. and Hunt, S.D., (1994). The commitment-trust theory of relationship marketing. Journal of Marketing, 58 (July): 20-38.

Nunnally, J. C. and Bernstein, I. H., (1994). Psychometric theory. New York: McGraw-Hall.

Payan, J.M. and McFarland, R.G., (2005). Decomposing influence strategies: argument structure and dependence as determinants of the effectiveness of influence strategies in gaining channel member compliance. Journal of Marketing, 69 (3): 66-79.

Perry, M.A.T., (2001). Channel member conflict and performance: a proposed model and research agenda. The International Review of Retailing, Distribution and Consumer Research, 1(2): 233- 252.

Pettit, J.D., Goris, J. R. and Vaught, B.C., (1997). An examination of organizational communication as a moderator of the relationship between job performance and job satisfaction. The Journal of Business Communication, 34 (1) (January): 81-98.

Ping, Jr R.A., (2003). Antecedents of satisfaction in a marketing channel. Journal of Retailing, 79 (4): 237-248.

Porterfield, T. E., (2008). Diversity in business-to-business information exchange: an empirical analysis of manufacturers and their trading partners. Transportation Journal, Summer: 36-47.

Razzaque, M. A. and Boon, T. G., (2003). Effects of dependence and trust on channel satisfaction, commitment and cooperation. Journal of Business-to-Business Marketing, 10(4): 23-48.

Robicheaux, R. A. and El-Ansary, A. I., (1975-76). A general model for understanding channel member behavior. Journal of Retailing, 52 (4): 13-94.

Rodri'guez, I.R. del B., Agudo, J. C. and Gutie'rrez, H.S.M., (2006). Determinants of economic and social satisfaction in manufacturer-distributor relationships. Industrial Marketing Management, 35: 666 675.

Rosenberg, L. J. and Stern, L.W., (1970). Toward the analysis of conflict in distribution channels: a descriptive model. The Journal of Marketing: 40-46.

Rosenberg, L. J. and Stern, L.W., (1971). Conflict measurement in the distribution channel. Journal of Marketing Research, 8 (November): 437-442.

Rosenbloom, B., (1973), Conflict and channel efficiency: some conceptual models for the decision maker. Journal of Marketing, 37 (July): 26-30.

Sashi, C.M., (2009). Conflict resolution strategies and marketing channel relationships: framework and research propositions. Journal of Global Business Management, 5(1): 63-169.

Scheer, L.K. and Stern, L.W., (1992). The effect of influence type and performance outcomes on attitude toward the influencer. Journal of Marketing Research, 29 (February): 128-142.

Schlegelmilch, B. B. and Penz, E., (2002). Knowledge management in marketing. The Marketing Review, 3(1): 5-19.

Schul, P.L., Little, T. E. and Pride, W. M., (1985). Channel climate: its impact on channel members' satisfaction. Journal of Retailing, 61 (2) (Summer): 9-38.

Schwab, D. P. and Cummings, L. L., (1970). Theories of performance and satisfaction: a review. Industrial Relations, 9: 408-430.

Skinner, S. J., Gassenheimer, J. B. and Kelley, S. W., (1992). Cooperation in supplier-dealer relations. Journal of Retailing, 68 (2): 174-192. 
Stank, T. P, Daugherty, P. J. and Ellinger, A. E., (1996a). Information exchange: responsiveness and logistics provider performance. The International Journal of Logistics Management, 7 (2): 43-57.

Stank, T.P., Emmelhainz, M. A. and Daugherty, P. J., (1996b). The impact of information on supplier performance. Journal of Marketing Theory and Practice, (Fall): 94-105.

Stern, L. and El-Ansary, A.I., (1977). Marketing channel. Englewood Cliffs, NJ: Prentice-Hall, Inc.

Valos, M. J. and Vocino, A., (2006). An integrative marketing channel performance measurement framework. Journal of Database Marketing \& Customer Strategy Management, 14 (1): 17-28.

Vlachos, I.P. and Bourlakis, M., (2006). Supply chain collaboration between retailers and manufacturers: do they trust each other?. Supply Chain Forum, 7 (1): 70-80.

Wang, G. and Olsen, J. E., (2002). Knowledge, performance, and exporter satisfaction: an exploratory study. Journal of Global Marketing, 15(3/4):39-64.

Whipple, J. M., Frankel, R. and Daugherty, P. J., (2002). Information support for alliances: performance implications. Journal of Business Logistics, 23(2): 67-82.

Wilkinson, I. F., (1981). Power, conflict and satisfaction in distribution channels- an empirical study. International Journal of Pyhsical Distribution and Materials Management, 11: 20-30.

Zaheer, A., Mcevily, B. and Perrone, V., (1998). Does trust matter? Exploring the effects of interorganizational and interpersonal trust on performance. Organization Science, 9 (2) (MarchApril): 141-159.

\section{APPENDIX 1: Measurement Items}

$\begin{array}{lll}\text { Construct } & \text { Study } & \text { Items } \\ \text { P1: In the last 2-3 years, we have continued to be able to improve product } \\ \text { design performance through this partnership } \\ \text { P2: In the last 2-3 years, we have continued to be able to improve process } \\ \text { design through this partnership } \\ \text { P3: In the last 2-3 years, we have continued to be able to improve product } \\ \text { quality through this partnership } \\ \begin{array}{l}\text { Kotabe et. } \\ \text { al. (2003) }\end{array}\end{array}$


(2007) T5: We trust the supplier

T6: We are comfort with giving information about our customer to the supplier

T7: The supplier does not make us ashamed in relationship with our customers

KT1: The supplier provides accurate information

KT2: The supplier provides information in a timely manner

KT3: We provide accurate information

KT4: We provide information in a timely manner

Whipple et

KT5: The information shared between my firm and the partner firm is more

al. (2002) detailed than the information shared with non-alliance firms

KT6: My firm increased the amount of operational information shared with the partner firm since the alliance begins

KT7: The partner firm has increased the amount of operational information shared with us since the alliance begins 